\title{
Impact of Frontline Demonstration Programme on the Yield of Chickpea (Cicer arietinum L.) in Mandla District of Madhya Pradesh, India
}

\author{
Vijay Singh Suryawanshi $^{1 *}$, Poornima Malviya ${ }^{2}$ and Vishal Meshram ${ }^{1}$ \\ ${ }^{1}$ Krishi Vigyan Kendra, Mandla, Jawaharlal Nehru Krishi Vishwa Vidyalaya, Jabalpur, \\ Madhya Pradesh, India \\ ${ }^{2}$ Department of Forestry, College of Agriculture, Jawaharlal Nehru Krishi Vishwa Vidyalaya, \\ Jabalpur, Madhya Pradesh, India \\ *Corresponding author
}

\begin{tabular}{|c|c|}
\hline & A B S T R A C T \\
\hline & \multirow{6}{*}{$\begin{array}{l}\text { The present study was carried out during Rabi season in five villages of Mandla district } \\
\text { during } 2011-12 \text { to } 2015-16 \text { in } 25 \text { ha by active participation of } 60 \text { numbers of farmers with } \\
\text { the objective to demonstrate the improved technology of chickpea production potential } \\
\text { These focused on increased the chickpea productivity and replacement of old variety with } \\
\text { promising high yielding improved variety, adoption of improved production technology } \\
\text { and get feedback from farmers on the performance of chickpea variety. The improved } \\
\text { production technology consisting use of modern variety, seed treatment with Trichodermo } \\
\text { viridae @ } 10 \mathrm{~g} / \mathrm{kg} \text {, Rhizobium culture @ } 5 \mathrm{~g} / \mathrm{kg} \text { and PSB @ } 10 \mathrm{~g} / \mathrm{kg} \text { of seed, balanced } \\
\text { fertilizer application on the basis of soil test value and pest management. Study revealed } \\
\text { that over the years, it was observed that the improved chickpea variety JG- } 63 \mathrm{recorded} \\
\text { higher yield }(1231 \mathrm{~kg} / \mathrm{ha} \text { ) as compared to the farmer's practices variety }(789 \mathrm{~kg} / \mathrm{ha} \text { ). The } \\
\text { increase in the research practices yield over farmer's practices was } 56.60 \% \text {. Technology } \\
\text { gap and the technology index values were } 568 \mathrm{~kg} / \mathrm{h} \text { and } 31.60 \text {, respectively. The research } \\
\text { practices gave higher gross return (Rs. } 41,932 / \mathrm{ha} \text { ), net return (Rs. } 27,296 / \mathrm{ha} \text { ) with higher } \\
\text { B: C ratio ( } 1: 3.43 \text { ) as compared to framer's practices. By conduction of front line } \\
\text { demonstrations on farmer's field there was significant increase in knowledge level of the } \\
\text { farmer's and majority of farmer's showed high level of satisfaction about research } \\
\text { practices. }\end{array}$} \\
\hline Keywords & \\
\hline $\begin{array}{l}\text { Chickpea, Frontline } \\
\text { demonstration, } \\
\text { Yield, Economics }\end{array}$ & \\
\hline Article Info & \\
\hline $\begin{array}{l}\text { Accepted: } \\
\text { 10 January } 2018 \\
\text { Available Online: } \\
10 \text { February } 2018\end{array}$ & \\
\hline & \\
\hline
\end{tabular}

\section{Introduction}

Chickpea (Cicer arietinum L.) is the largest produced food legume in south Asia and the $3^{\text {rd }}$ largest produced food legume globally after common bean and field pea. Chickpea is one of important pulse crop in India, accounting 75 percent of world production. The area, production and productivity of chickpea in Madhya Pradesh is 2630 (000) ha, 2845 (000) MT and $1082 \mathrm{~kg} / \mathrm{ha}$ respectively. The area, production and productivity of chickpea in Mandla district is 9.3 (000) ha, 5.7 (000) MT and $608 \mathrm{~kg} / \mathrm{ha}$ respectively (Anonymous, 2011). Hence the productivity is far below potential yield (Avg. 20q/ha). The concept of front line demonstrations in India was put forth under a "Technology Mission on 
Pulses" in 1991-92. The main objective of front line demonstrations is to demonstrate newly released crop production technologies and its management practices in the farmer's field under farming situations and at different agroclimatic regions (Meena, 2011 and Narasimha Rao et al., 2007). The field demonstrations conducted under the close supervision of scientists of the National Agriculture Research System is called frontline demonstrations because the technologies are demonstrated and critically examined by the scientists themselves before being fed into the main extension system of the State Department of agriculture. While demonstrating the technologies in the farmer's field, the scientists are required to study the factors contributing to higher crop production, production constraints and thereby, generate production data and feedback information. Front-Line Demonstrations are conducted in a block of two or four hectares land in order to have better impact of the demonstrated technologies on the famers as well as field level extension functionaries. The newly and innovative technology having higher production potential under the specific cropping system can be popularized through FLD programme. The present study has been undertaken to evaluate the difference between demonstrated technologies vis-à-vis practices followed by the local farmers in chickpea crop.

\section{Materials and Methods}

The present study was carried out by the Krishi Vigyan Kendra, Mandla, Jawaharlal Nehru Krishi Vishwa Vidyalaya, M.P. in rabi season in the farmers field of five villages of Mandla district during 2011-12 to 2015-16. All 60 front line demonstrations in 25 ha area were conducted in different villages with active participation of farmer. The Indian Council of Agricultural Research has implemented a new fully funded programme in mid-eighties. i.e. Front Line Demonstrations for transfer of technology to farmers. The objective of FLD's was to transfer the improved technology to increase the productivity of chickpea through various types of Demonstrations viz., varietal, fertilizer management, Rhizobium inoculation, plant protection, IPM, "Seeing is believing" was the basic philosophy of FLDs. Before conducting FLDs a list of farmers was prepared from group meeting and specific skill training was imparted to the selected farmers regarding different aspect of cultivation (Venkattakumar et al., 2010). The difference between demonstration package and existing farmers practice are given in Table 1 .

All demonstrations were conducted on medium black soils. The improved chickpea variety JG-63 is sown in rows $30 \mathrm{~cm}$ apart at the rate of $80 \mathrm{~kg}$ seed/ha. The inputs like improved variety, recommended dose of fertilizers, biofertilizers and insecticides/pesticides and IPM kits were supplied to the farmers. Farmers were advised to use proper seed rate with recommended package of practices. The sowing method keeping $30 \times 10 \mathrm{~cm}$ spacing was demonstrated on their fields. A basal application of $20 \mathrm{~kg}$ $\mathrm{N}+40 \mathrm{~kg} \mathrm{P}_{2} \mathrm{O}_{5} / \mathrm{ha}$ in the form of DAP and urea and sulphur @ 20kg/ha as per recommendations were given. The seed was treated before sowing with Trichoderma @ 10 gm/kg, Rhizobium culture @ 5 gm $/ \mathrm{kg}$ and PSB culture with $10 \mathrm{gm} / \mathrm{kg}$ and thirum @ $2 \mathrm{gm} / \mathrm{kg}$ of seed as per recommendations to control pest infestation. Plant protection measures were under taken as per necessary. The necessary steps for selection of site and farmers, layout of demonstration etc. were followed as suggested by Choudhary (1999). The data output were collected from both RP as well as farmers practices and finally the extension gap, technology gap, technology index along with benefit cost ratio were workout (Samui et al., 2000) as given below: 
Technology gap $=$ Pi $($ Potential yield $)-$ Di (Demonstration yield)

Extension gap $=$ Di $($ Demonstration yield $)-F i$ (Farmers Yield)

Technology index $(\%)=($ Technology gap $/$ Potential yield) $\times 100$

\section{Results and Discussion}

\section{Yield}

From the data presented in the Table 2 it is concreted that in frontline demonstration yield (IT) of JG-63 variety performed better than traditional farmer practices. The JG-63 recorded maximum and minimum yield in Rabi season year 2012-13 and 2014-15 with $1597 \mathrm{~kg} / \mathrm{ha}$ and $873 \mathrm{~kg} / \mathrm{ha}$, respectively. The average yield of five years was recorded 1231 $\mathrm{kg} / \mathrm{ha}$ as compared to local variety $789 \mathrm{~kg} / \mathrm{ha}$. The percent increase in yield was ranging from 42.7 to 72.64 during the study. Similar yield enhancement in different crops in frontline demonstration has been documented by Poonia and Pithia (2011), Patel et al., (2013) and Raj et al., (2013). It is evident from the results that the yield of improved variety was found better than the local variety under same environment conditions. Farmers were motivated by results of demonstrated agro-technologies applied in the FLDs and it is anticipated that they would adopt these technologies in future. Yield of front line demonstration and potential yield of the crop was compared to estimate the yield gaps which were further categorized into technology index.

\section{Technology gap}

The technology gap is the demonstration yield over potential yield. The technology gap was ranged between $203-922 \mathrm{~kg} / \mathrm{ha}$ with a mean of five years $568 \mathrm{~kg} / \mathrm{ha}$ during period of study.
The technology gap may be attributed to the dissimilarity in the soil fertility status and weather conditions (Mukherjee, 2003 and Mitra and Samajdar, 2010).

\section{Extension gap}

The highest extension gap was $672 \mathrm{~kg} / \mathrm{ha}$ recorded in the year 2012-13 and minimum $342 \mathrm{~kg} / \mathrm{ha}$ was observed in the year 2013-14. This emphasized the need to educate the farmers through various means for the adoption of improved agricultural production technologies to reverse this trend of wide extension gap. More and more use of latest production technologies with high yielding variety will subsequently change this alarming trend of galloping extension gap. The new technologies will eventually lead to the farmers to discontinue the old technology and to adopt new technology (Table 2). This finding is in corroboration with the findings of Hiremath and Nagaraju (2010).

\section{Technology index}

The technology index shows the feasibility of the technology at the farmer's field. The lower the value of technology index more is the feasibility.

As such, fluctuation in the technology index was from 11.28 to 51.22 per cent during period of study (Table 2). These findings corroborate with the findings of Mokidue et al., (2011) and Tomar (2003).

\section{Economics of frontline demonstrations}

The year wise economics of gram cultivation with adoption of improved technology and farmers practices has been presented in Table 3 . The results of economic analysis of gram production revealed that the gross expenditure in demonstration practices was higher than farmer's practices by about $24.44 \%$. 
Table.1 Recommended practices and farmer's practices in chickpea crop

\begin{tabular}{|c|c|c|c|}
\hline S. No. & Component & Recommended Practices & Farmers Practices \\
\hline 1. & Variety & JG-63 & Local \\
\hline 2. & Seed rate & $80 \mathrm{~kg} / \mathrm{ha}$ & $20 \%$ higher \\
\hline 3. & Seed treatment & $\begin{array}{l}\text { Trichodermaviridae@10g/kg, Rhizobium culture@5g/kg, PSB } \\
\text { @ } 5 \mathrm{~g} / \mathrm{kg} \text { and thirum @ } 2 \mathrm{gm} / \mathrm{kg}\end{array}$ & No seed treatment \\
\hline 4. & Spacing & $30 \times 10 \mathrm{~cm}$ & Not followed \\
\hline 5. & Fertilizer dose & 20:60:20 NPK kg/ha & Imbalance use of fertilizer \\
\hline 6. & Weed management & One mechanical weeding & As and when needed \\
\hline 7. & Plant Protection & Need based application & Indiscriminate use without proper dose \\
\hline
\end{tabular}

Table.2 Productivity, technology gap, extension gap and technology index of chickpea under FLDs

\begin{tabular}{|c|c|c|c|c|c|c|c|c|c|}
\hline \multirow{2}{*}{$\begin{array}{l}\text { S. } \\
\text { No. }\end{array}$} & \multirow[t]{2}{*}{ Year } & \multirow{2}{*}{$\begin{array}{c}\text { No. } \\
\text { of farmers }\end{array}$} & \multirow{2}{*}{$\begin{array}{c}\text { Area } \\
\text { (ha) }\end{array}$} & \multicolumn{2}{|c|}{ Yield(kg/ha) } & \multirow{2}{*}{$\begin{array}{c}(\%) \text { Increase } \\
\text { over FP }\end{array}$} & \multirow{2}{*}{$\begin{array}{c}\text { Technology gap } \\
\text { (kg/ha) }\end{array}$} & \multirow{2}{*}{$\begin{array}{l}\text { Extension gap } \\
\text { (kg/ha) }\end{array}$} & \multirow{2}{*}{$\begin{array}{l}\text { Technology } \\
\text { Index }(\%)\end{array}$} \\
\hline & & & & $\begin{array}{l}\text { Research } \\
\text { Practices }\end{array}$ & $\begin{array}{l}\text { Farmer's } \\
\text { Practices }\end{array}$ & & & & \\
\hline 1 & 2011-12 & 12 & 5 & 1427 & 1000 & 42.70 & 373 & 427 & 20.72 \\
\hline 2 & $2012-13$ & 12 & 5 & 1597 & 925 & 72.64 & 203 & 672 & 11.28 \\
\hline 3 & 2013-14 & 12 & 5 & 1054 & 712 & 48.03 & 746 & 342 & 41.44 \\
\hline 4 & $2014-15$ & 12 & 5 & 878 & 532 & 65.03 & 922 & 346 & 51.22 \\
\hline 5 & $2015-16$ & 12 & 5 & 1200 & 776 & 54.63 & 600 & 424 & 33.33 \\
\hline & Average & 12 & 5 & 1231 & 789 & 56.60 & 568 & 442 & 31.60 \\
\hline
\end{tabular}

Table.3 Economics of frontline demonstrations

\begin{tabular}{|c|c|c|c|c|c|c|c|c|}
\hline \multirow[t]{2}{*}{ Year } & \multicolumn{2}{|c|}{ Cost of Cultivation (Rs/ha) } & \multicolumn{2}{|c|}{ Gross Return (Rs/ha) } & \multicolumn{2}{|c|}{ Net Return (Rs/ha) } & \multicolumn{2}{|c|}{ B:C ratio } \\
\hline & $\begin{array}{l}\text { Research } \\
\text { Practices }\end{array}$ & $\begin{array}{l}\text { Farmer's } \\
\text { practices }\end{array}$ & $\begin{array}{l}\text { Research } \\
\text { Practices }\end{array}$ & $\begin{array}{c}\text { Farmer's } \\
\text { practices }\end{array}$ & $\begin{array}{l}\text { Research } \\
\text { Practices }\end{array}$ & $\begin{array}{l}\text { Farmer's } \\
\text { practices }\end{array}$ & $\begin{array}{l}\text { Research } \\
\text { Practices }\end{array}$ & $\begin{array}{l}\text { Farmer's } \\
\text { practices }\end{array}$ \\
\hline 2011-12 & 12878 & 10500 & 51810 & 30000 & 29932 & 19500 & 4.02 & 2.85 \\
\hline 2012-13 & 12000 & 10000 & 55895 & 32376 & 40495 & 24375 & 4.65 & 3.23 \\
\hline 2013-14 & 12400 & 8800 & 31625 & 21360 & 19225 & 12560 & 2.55 & 2.42 \\
\hline 2014-15 & 11000 & 9200 & 30730 & 18620 & 19730 & 9420 & 2.79 & 2.02 \\
\hline $2015-16$ & 12500 & 10500 & 39600 & 25608 & 27100 & 13108 & 3.16 & 2.43 \\
\hline Average & 12156 & 9800 & 41932 & 25593 & 27296 & 15793 & 3.43 & 2.59 \\
\hline
\end{tabular}


But, front line demonstrations recorded higher gross returns (Rs. 41,932/ha) and net return (Rs. 27,296/ha). The benefit cost ratio of demonstration practices (1:3.29) also more than the farmer's practice.

Sreelakshmi et al., (2012), Joshi et al., (2014) and Sharma et al., (2016) also reported higher net returns and $\mathrm{B}: \mathrm{C}$ ratio in the FLDs on improved technologies compared to the farmer's practices and are at par with results in higher net returns through FLDs on improved technologies.

The findings of the study revealed that wide gap exist in demonstration yield and farmer's practices in gram varieties due to technology and extension gap in Mandla District of MP. The percent increment in yield of gram to the extent of $56 \%$ in FLDs over the farmers' practices created greater awareness and motivated the other farmers to adopt the improved package of practices of gram. These demonstrations trails also enhance the relationship and confidence between farmers and KVK scientists. The recipient farmers of FLDs also play an important role as source of information and quality seeds for wider dissemination of the improved varieties of gram for other nearby farmers. It is concluded that the FLD programme is a successful tool in enhancing the production and productivity of gram crop through changing the knowledge, attitude and skill of farmers.

\section{References}

Anonymous, 2011. www.mpkrishi.org

Choudhary, B. N. 1999. Krishi Vigyan Kendra- a guide for KVK manager. Division of Agriculture Extension, ICAR, pp. 73-78.

Hiremath, S. M. and Nagaraju, M. V. 2010. Evaluation of on-farm front line demonstrations on the yield of chilli. Karnataka Journal of Agricultural
Sciences, 23(2):341-342.

Joshi, N. S. Bariya, M. K. and Kunjadia, B. B. 2014. Yield gap analysis through front line demonstrations in wheat crop. International Journal of Scientific Research Publication, 4(9):1-3.

Meena, K. C. 2011. An impact assessment of frontline demonstrations (flds) on soybean growers. Rajasthan. Journal of Extension Education, 19:133-138.

Mitra, B. and Samajdar, T. 2010. Field gap analysis of rapeseed-mustard through front line demonstration. Agricultural Extension Review, 22: 16-17.

Mokidue, I. Mohanty, A. K. and Sanjay, K. 2011. Corelating growth, yield and adoption of urdbean technologies, Indian Journal of Extension Education, 11(2):20-24.

Mukherjee N. 2003. Participatory, learning and action. Concept, Publishing Company, New Delhi, Pp. 63-65.

Narasimha, Rao, S., Satish, P. and Samuel, G. 2007. Productivity improvement in soybean (Glycine $\max$ L. Merrill) through technological interventions. Journal of Oilseeds Research, 24(2): 271-273.

Patel, M. M., Jhajharia, A. K., Khadda, B. S. and Patil, L. M. 2013. Front-line Demonstration: An effective Communication Approach For dissemination of sustainable cotton production technology. Indian Journal of Extension Education and Rural Development, 21:60-62.

Poonia, T. C. and Pithia M.S. 2011. Impact of front line demonstrations of chickpea in Gujrat. Legume Research, 34(4):304307.

Raj, A. D., Yadav, V. and Rathod, J. H.2013. Impact of Front Line Demonstrations (FLD) on the yield of pulses. International Journal of Scientific and Research Publications. Volume 3, Issue 9, September 2013. 
Samui, S. K., Maitra, S., Roy, D. K., Mandal, A.K. and Saha, D. 2000. Evaluation of front line demonstration on groundnut (Arachis hypogeal L.) Journal of Indian Society of Coastal Agricultural Research, 18(2):180-183.

Sharma, Vivek, Kumar, V. Sharma, S. C. and Singh, S. 2016. Productivity enhancement and popularization of improved production technologies in wheat through frontline demonstrations. Journal of Applied Natural Science, 8(1):423-428.

Sreelakshmi, C. H., Sameer Kumar, C. V. and Shivani, D. 2012. Productivity enhancement of pigeonpea (Cajanus cajan L.) through improved production technology. Madras Agricultural Journal, 99 (4-6):248-250.

Tomar, L. S., Sharma, B. P. and Joshi, A. 2003. Impact of frontline demonstration of soybean in transfer of improved technology. Journal of Extension Education, 22(1):139.

Venkattakumar, R., Ramana Rao, S. V. Padmaiah, M. and Madhuri, P. 2010. Production constraints and information needs of oilseeds growers in Andhra Pradesh. Agricultural Extension Review, 22(2):25-28.

\section{How to cite this article:}

Vijay Singh Suryawanshi, Poornima Malviya and Vishal Meshram. 2018. Impact of Frontline Demonstration Programme on the Yield of Chickpea (Cicer arietinum L.) in Mandla District of Madhya Pradesh, India. Int.J.Curr.Microbiol.App.Sci. 7(02): 1022-1027.

doi: https://doi.org/10.20546/ijcmas.2018.702.126 